\title{
THE USE OF DICTIONARY TO UNDERSTAND SIMILAR WORDS IN ENGLISH
}

\author{
Najamuddin \\ TBI Fakultas Tarbiyah Dan Keguruan UIN Mataram \\ najamuddin@uinmataram.ac.id
}

\begin{abstract}
A knowledge of words, phrases, clauses is essential to good writting and speaking, but it doesn't mean neglect the other part of grammar. The correction of writing and speaking is to concentrate on what we are saying rather than on how we are saying it. The problems might raise once speakers find similar words in meaning but cotextually different in use. The study aims to investigate the forms of words that have more than one correct meaning but different in use. The data were collected by sorting some potential words that have the same meanings in the dictionary as a content analysis. The words were investigated in the dictionary and provided their meanings in forms of tables. The words were analysed qualitatively by looking at the meaning prescribed in dictionary and compared how they are used in a sentence. It is found that words serve different purposes in language. Some words seem to have function words that cue a reader or speaker to the structure of the sentence such as are, that, $a$, to, or, the, of, and so forth. Function words make spoken language meaningful and written language coherent and readable. Other words might refer as content words that communicate meaning in text. Clearly, students must know both kinds of words to understand what they read.
\end{abstract}

Keyword: English words, similar form and sound

\section{A. Introduction}

Speaking correctly and effectively is considered not only crucial for courses in English, but also useful to understand any school subject, including the social sciences, and mathematics. Most standardized and school admission test that students take emphasize the ability to use the English language. Writing and speaking skills are also important tools for getting a job and trying to advance in chosen career. Students still find some number of English difficult words to learn and understand, students confused about how to spell them and apply in everyday situations(Baxter,1980)1. This confusion is due to countless rules governing proper grammar and writing.

As we knew, English words are number of words that has convention used in spoken and written that helps to guide the use of correctly. Good words are like good table manner. When one is speaking, the language used varies naturally and

1 Baxter, James. (1980). The Dictionary and Vocabulary Behavior: A Single Word or a Handful? TESOL Quarterly, 14 (3), 325-336. 
it really depens on the circumstances. However, although word choice may change when speaking to parents, teachers, friends and the others, the goal is still the same: communication of ideas(Christianson, 1997). ${ }^{2}$

A knowledge of words, phrases, clauses is essential to good writting and speaking, but it doesn't mean neglecting the other part of grammar. The correction of words is to concentrate on what we are saying rather than on how we are saying it.

Dictionary of the English Language as it written and spoken by educated people includes students is lists word, compound words and isiomatic expressions that the learner is likely to come across in everyday English speech, in official and informal writing, and in the literature of the $20^{\text {th }}$ and $19^{\text {th }}$ centuries. For all the listed items there is information on spelling, pronounciation, grammatical use, and meaning or meanings. ${ }^{3}$

Good writers must have an understanding of basic material with which they works: Ideas and pronounciation, both simple and complex, require words of several kinds-for example, naming words, asserting words, connecting words, descriptive words. This knowledge involves what word like, where it appears, and what it does within its context. That is why a writer must continually strive for precice expression and economy of language finding the exact word to express a specific meaning. Therefore, the dictionary becomes indispensible.

\section{B. Theoretical Background}

Establishing exactly what it means to know a word is no easy task. Is "knowing" a word being able to recognize what it looks and sounds like? Is it being able to give the word's dictionary definition? Research suggests that, in general, the answer to these questions is no. Knowing a word means knowing how to use the word correctly and understanding it rather than just knowing it by paying attention on the sight and sound only. Both oncepts are totally different since the context plays very important role (Miller \& Gildea, 1987). ${ }^{4}$

Instruction in dictionary use simple way that get students to look up words and write definitions, but seldom to produce indepth word knowledge (Scott $\&$ Nagy, 1997). ${ }^{5}$ This is not to say that dictionaries are not beneficial aids to a word learning, rather it indicates that instruction must show students how to use the definitions they find in a dictionary.

2 Christianson, Kiel. (1997). Dictionary use by EFL writers: what really happens? Journal of Second Language Writing, 6 (1), 23-43.

3 Hornby, A. Oxford Advanced Learner's Dictionary of Current English. (Oxford: Oxford University Press, 1987), h. xiii.

4 Miller, G., \& Gildea, P. How Children Learn Words. (Scientific American, 1987),h. 27, 94-99.

5 Scott, J. A., \& Nagy, W. E. Understanding the definitions of unfamiliar verbs. Reading Research Quarterly,(1997),h. 32, 184-200. 
The study approach is simply limited to use the right words by using English Dictionary when they have similar forms and sounds of words.In the Dictionary the words explained are arranged regularly. According to Fogiel ${ }^{6}$ the dictionary is the place to look when one is not sure how to spell a word. There are some words that have more than one correct spelling. The forms, which are equally acceptable, are seperated in the dictionary by a comma or the word. Some examples are modeled, modelled; judgment, judgement; align, aline; catalog, catalogue. If one spelling is not as another, the word also will precede the less acceptable spelling: color, also colour. British spellings are often given after American spelling and are also set off by comma: theater, theathre; connection, connexion; favor, favour.

Words serve different purposes in language. There are two kinds of words that need to be considered in order to have such comprehensive understanding both text and context. First, function words that provide explain words with structure of the sentences : are, that, $a$, to, or, the, of, and so forth. Function words help speakers and readers understand words meaningfully, coherently and read easily both spoken and written communication(Stahl and Nagy, 2000). ${ }^{7}$ Second, content words are the words that serve meaning in text. It helps speaker and reader understand the literal meaning of words and sentences in particular text. Clearly, students must know both kinds of words to understand what they read (Julian, 2000). ${ }^{8}$

An intereseting question then raised, how do students acquire so many new words? An extensive study indicates that the answer to this question is through incidentallearning. It means that the learing is conducted through exposure and interaction with very complex and rich oral language and by encountering lots of new words in text, either through their own reading or by being read. However, such incidental encounters may not result that students will gain indepth meanings of specific words. For some words, such as those that are crucial for understanding a literature selection or a content area concept, most students need to have intentional

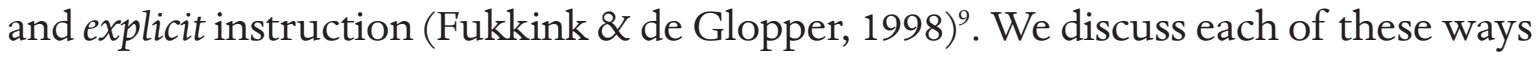
to acquire vocabulary in later sections. First, however, we are "knowing" a word means.

In written and spoken English, words can often be pronounced in different ways. The complex nature of language sometimes makes writting difficult. Words often become confusing when they have similar forms and sounds(Oelschlaeger and Damico, 2000 $)^{10}$. Indeed, an author may have correct meaning in mind, but an incorrect

6 Fogiel. M. REA's Hand Book English Grammar, Style, and Writing. Research and Education Association 61 Ethel Road West Piscataway.(New Jersey 08854. Printed in the USA, 1994), h. 17.

7 Stahl, S.A.,\& Nagy, W.E.( 2000).Teaching Words Meaning. L. Erlbaum Associates, USA.

8 Jullian, Paul. (2000). Creating word-meaning awareness. ELT Journal, 54 (1), 37-46

9 Fukkink, R. G., \& de Glopper, K. (1998). Effects of instruction in deriving word meaning from context: A meta-analysis. Review of Educational Research, 68(4), 450-468.

10 Oelschlaeger, Mary L., Damico, Jack S. (2000). Partnership in conversation: A study of word search strategies. Journal of Communication Disorder, 33 (3), 205-225. 
word choice can alter the meaning of sentence or even make it totally illogical. That is why a writer must continually strive for precise expression of language by finding the exact word to express a specific meaning.

\section{Research Method}

The present content analysis tends to investigate potential words in the dictionary. Content analysis is a research to identify the meaning from certain document or achive (Mile, Huberman, Saldana, 2013) ${ }^{11}$. The data collection was conducted by looking at samples of words that potentially have more than one meaning and analyse them qualitatively by investigating the meaning and the use in some sentences to know meaning and the contexts(Stahl \& Nagy, 2000). The words are prescribed in the sentences in order to differentiate the meaning and then to be identified as what lexically and contextually prescribed at dictionary. The definition and the use of the words in the sentences will provide clear understanding of those similar words meaning.

\section{Discussion}

Unfortunately (for instructional purposes), the number of content words is virtually unlimited. Because of this, the criterion for word selection, the usefulSome similar form and sound in english words, and many people find it confusing that leads them misuse when writing. This list might be used as a reference onceyou are not sure about which word its in the contextness- the frequency with which it is likely to appear in text - must be considered.

\begin{tabular}{|l|l|}
\hline Word & Meaning \\
\hline Accent & Stress or emphasize. (You must accent the last sylable) \\
\hline Ascent & A climb or rise. (Jhon's ascent of the mountain was dengerous) \\
\hline Advice & $\begin{array}{l}\text { Opinion given as to what to do or how handle a situation. (Her sister } \\
\text { gave her advice on what to say at interview) }\end{array}$ \\
\hline Advise & $\begin{array}{l}\text { Counsel. (Jhon's guidance counselor advised him on which college to } \\
\text { apply to) }\end{array}$ \\
\hline Affect & $\begin{array}{l}\text { Usually a verb that means to have an influence on: "His loud humming } \\
\text { was affecting my ability to concentrate." }\end{array}$ \\
\hline
\end{tabular}

11 Miles, M. B., Huberman, A. M., \& Saldana, J. (2013). Qualitative Data Analysis: A Methods Sourcebook. Sage Publications, Incorporated. 


\begin{tabular}{|c|c|}
\hline Effect & $\begin{array}{l}\text { Usually a noun that means a result or the power to produce a result: } \\
\text { "The sound of the falling rain had a calming effect, nearly putting me } \\
\text { to sleep } \\
\text { Note that effect can also be a verb meaning to bring about or execute: } \\
\text { "The speaker's somber tone effected a dampening in the general mood } \\
\text { of the audience." }\end{array}$ \\
\hline $\begin{array}{l}\text { all right / } \\
\text { alright }\end{array}$ & $\begin{array}{l}\text { Satisfactory or acceptabe. It is commonly used but is considered as } \\
\text { nonstandard English. As the American Heritage Dictionary notes, it's not } \\
\text { "all right to use alright." }\end{array}$ \\
\hline $\begin{array}{l}\text { all together } \\
\text { / altogether }\end{array}$ & $\begin{array}{l}\text { Used toindicate people or things that are considered as a group. "We } \\
\text { put the pots and pans all together on the shelf." } \\
\text { Altogether is used to mean completely or entirely: "I am altogether } \\
\text { pleased to be receiving this award." }\end{array}$ \\
\hline Allusion & $\begin{array}{l}\text { A noun that means an indirect reference: "The speech made allusions } \\
\text { to the final report." }\end{array}$ \\
\hline Illusion & $\begin{array}{l}\text { A noun that means a misconception: "The policy is designed to give an } \\
\text { illusion of reform." }\end{array}$ \\
\hline Alternately & $\begin{array}{l}\text { An adverb that means in turn; one after the other: "We alternately } \\
\text { spun the wheel in the game." }\end{array}$ \\
\hline Alternatively & $\begin{array}{l}\text { An adverb that means on the other hand; one or the other: "You } \\
\text { can choose a large bookcase or, alternatively, you can buy two small } \\
\text { ones." }\end{array}$ \\
\hline Beside & A preposition that means next to: "Stand here beside me." \\
\hline Besides & $\begin{array}{l}\text { An adverb that means also: "Besides, I need to tell you about the new } \\
\text { products my company offers." }\end{array}$ \\
\hline Capital & The city or town where the seat of government is located \\
\hline Capitol & $\begin{array}{l}\text { The building in which the legislative assembly meets. The term capital } \\
\text { can also refer to an accumulation of wealth or to a capital letter }\end{array}$ \\
\hline
\end{tabular}




\begin{tabular}{|c|c|}
\hline Cite & $\begin{array}{l}\text { A verb that means to quote as an authority or example: "I cited several } \\
\text { eminent scholars in my study of water resources." It also means to } \\
\text { recognize formally: "The public official was cited for service to the } \\
\text { city." It might also mean to call them before a court of law: "Last year } \\
\text { the company was cited for pollution violations." }\end{array}$ \\
\hline Site & $\begin{array}{l}\text { A noun meaning location: "They chose a new site for the factory just } \\
\text { outside town." }\end{array}$ \\
\hline Compliment & $\begin{array}{l}\text { A noun or verb that means something that completes or makes up a } \\
\text { whole: "The red sweater is a perfect complement to the outfit." }\end{array}$ \\
\hline Compliment & $\begin{array}{l}\text { A noun or verb that means an expression of praise or admiration: "I } \\
\text { received compliments about my new outfit." }\end{array}$ \\
\hline Councilor & $\begin{array}{l}\text { A member of a council, which is an assembly called together for } \\
\text { discussion or deliberation }\end{array}$ \\
\hline Counselor & $\begin{array}{l}\text { One who gives counsel,it might be advice or guidance on personal, } \\
\text { social or psychological problems. More specifically, a counselor can be } \\
\text { an attorney or a supervisor at camp }\end{array}$ \\
\hline Discreet & $\begin{array}{l}\text { An adjective that means prudent, circumspect, or modest: "Her discreet } \\
\text { handling of the touchy situation put him at ease." }\end{array}$ \\
\hline \multirow[t]{2}{*}{ Discrete } & $\begin{array}{l}\text { An adjective that means separate or individually distinct: "Each } \\
\text { company in the conglomerate operates as a discrete entity." }\end{array}$ \\
\hline & $\begin{array}{l}\text { An adjective that means unbiased or impartial: "We appealed to the } \\
\text { disinterested mediator to facilitate the negotiations." }\end{array}$ \\
\hline Uninterested & $\begin{array}{l}\text { An adjective that means not interested or indifferent: "They seemed } \\
\text { uninterested in our offer." }\end{array}$ \\
\hline Elicit & A verb that means to draw out. \\
\hline Illicit & $\begin{array}{l}\text { An adjective meaning unlawful. "No matter how hard I tried to elicit } \\
\text { a few scandalous stories from her, she kept all knowledge of illicit } \\
\text { goings-on discreetly to herself." }\end{array}$ \\
\hline emigrant & $\begin{array}{l}\text { Emigrant is a noun that means one who leaves one's native country to } \\
\text { settle in another: "The emigrants spent four weeks aboard ship before } \\
\text { landing in Los Angeles." }\end{array}$ \\
\hline Immigrant & $\begin{array}{l}\text { A noun that means one who enters and settles in a new country: "Most } \\
\text { of the immigrants easily found jobs." One emigrates from a place; one } \\
\text { immigrates to another. }\end{array}$ \\
\hline
\end{tabular}




\begin{tabular}{|c|c|}
\hline Farther & $\begin{array}{l}\text { An adjective and adverb that means to or at a more distant point: "We } \\
\text { drove } 50 \text { miles today; tomorrow, we will travel } 100 \text { miles farther." }\end{array}$ \\
\hline Further & $\begin{array}{l}\text { An adjective and adverb that means to or at a greater extent or degree: } \\
\text { "We won }>\text { t be able to suggest a solution until we are further along in our } \\
\text { evaluation of the problem." It can also mean in addition or moreover: } \\
\text { "They stated further that they would not change the policy." }\end{array}$ \\
\hline Few & $\begin{array}{l}\text { An adjective that means small in number. It is used with countable } \\
\text { objects: "This department has few employees." }\end{array}$ \\
\hline Less & $\begin{array}{l}\text { An adjective that means small in amount or degree. It is used with } \\
\text { objects of indivisible mass: "Which jar holds less water?" }\end{array}$ \\
\hline Figuratively & $\begin{array}{l}\text { An adverb that means metaphorically or symbolically: "Happening } \\
\text { upon the shadowy figure, they figuratively jumped out of their } \\
\text { shoes." }\end{array}$ \\
\hline Literally & $\begin{array}{l}\text { An adverb that means metaphorically or symbolically: "Happening } \\
\text { upon the shadowy figure, they figuratively jumped out of their } \\
\text { shoes." }\end{array}$ \\
\hline $\begin{array}{l}\text { flammable / } \\
\text { inflammable }\end{array}$ & $\begin{array}{l}\text { These two words are synonyms even tough they look like opposites, } \\
\text { both mean easily tend to catch fire. The highly flammable (inflammable) } \\
\text { fuel was stored safely in a specially built tank. Use nonflammable to } \\
\text { mean not flammable. }\end{array}$ \\
\hline Flaunt & $\begin{array}{l}\text { To flaunt means to show off shamelessly: "Eager to flaunt her } \\
\text { knowledge of a wide range of topics, Helene dreamed of appearing } \\
\text { on a TV trivia show." }\end{array}$ \\
\hline Flout & $\begin{array}{l}\text { To flout means to show scorn or contempt for: "Lewis disliked boarding } \\
\text { school and took every opportunity to flout the house rules." }\end{array}$ \\
\hline Foreword & $\begin{array}{l}\text { A noun that means an introductory note or preface: "In my foreword I } \\
\text { explained my reasons for writing the book." Forward is an adjective or } \\
\text { adverb that means toward the front: "I sat in the forward section of the } \\
\text { bus." "Please step forward when your name is called." }\end{array}$ \\
\hline Forward & $\begin{array}{l}\text { A verb that means to send on: "Forward the letter to the customer }>\text { s } \\
\text { new address." }\end{array}$ \\
\hline $\begin{array}{l}\text { founder } \\
\text { flounder }\end{array}$ & $\begin{array}{l}\text { In its primary sense founder means to sink below the surface of the } \\
\text { water: "The ship foundered after colliding with an iceberg." By } \\
\text { extension, founder means to fail utterly. } \\
\text { Flounder means to move about clumsily, or to act with confusion. A } \\
\text { good synonym for flounder is blunder: "After floundering through the } \\
\text { first half of the course, Amy finally passed with the help of a tutor." }\end{array}$ \\
\hline
\end{tabular}




\begin{tabular}{|c|c|}
\hline Hanged & $\begin{array}{l}\text { The past tense and past participle of hang when the meaning is to } \\
\text { execute by suspending by the neck: "They hanged the prisoner for } \\
\text { treason." "The convicted killer was hanged at dawn." }\end{array}$ \\
\hline Hung & $\begin{array}{l}\text { The past tense and participle of hang when the meaning is to suspend } \\
\text { from above with no support from below: "I hung the painting on the } \\
\text { wall." "The painting was hung at a crooked angle." }\end{array}$ \\
\hline $\begin{array}{l}\text { historic / } \\
\text { historical }\end{array}$ & $\begin{array}{l}\text { In general usage, historic refers to what is important in history, while } \\
\text { historical applies more broadly to whatever existed in the past whether } \\
\text { it was important or not: "a historic summit meeting between the prime } \\
\text { ministers;" "historical buildings torn down in the redevelopment." }\end{array}$ \\
\hline i.e. / e.g. & $\begin{array}{l}\text { The abbreviation e.g. means for example (from Latin exempli gratia): } \\
\text { "Her talents were legion and varied (e.g., deep sea diving, speed } \\
\text { reading, bridge, and tango dancing)." The abbreviation i.e. means that } \\
\text { is or in other words (from Latin id est): "The joy of my existence (i.e., } \\
\text { my stamp collection) imbues my life with meaning." }\end{array}$ \\
\hline it $>s /$ its & $\begin{array}{l}\text { It }>s \text { is a contraction for it is, whereas its is the possessive form of it: } \\
\text { "It's a shame that we cannot talk about its size." }\end{array}$ \\
\hline Laid & $\begin{array}{l}\text { It is the past tense and the past participle of the verb "lay", not the past } \\
\text { tense of lie. }\end{array}$ \\
\hline Lay & $\begin{array}{l}\text { The past tense of the verb lie and lain is the past participle: "He laid } \\
\text { his books down and lay down on the couch, where he has lain for an } \\
\text { hour." }\end{array}$ \\
\hline lend / loan & $\begin{array}{l}\text { Although some people feel loan should only be used as a noun, lend and } \\
\text { loan are both acceptable as verbs in standard English: "Can you lend } \\
\text { (loan) me a dollar?" However, only lend should be used in figurative } \\
\text { senses: "Will you lend me a hand?" }\end{array}$ \\
\hline $\begin{array}{l}\text { lightening / } \\
\text { lightning }\end{array}$ & $\begin{array}{l}\text { Lightening is a verb that means to illuminate; } \\
\text { lightning is a noun referring to the electrical charges the cause flashes of } \\
\text { light during storms: "The lightning struck, lightening the sky." }\end{array}$ \\
\hline passed / past & $\begin{array}{l}\text { Passed is the past tense and past participle of pass. Past indicates to time } \\
\text { gone by, it is also a preposition meaning beyond. "In the past decade, I } \\
\text { passed over countless opportunities; I was determined not to let them } \\
\text { get past me again." }\end{array}$ \\
\hline
\end{tabular}




\begin{tabular}{|c|c|}
\hline $\begin{array}{l}\text { precede } \\
\text { proceed }\end{array}$ & $\begin{array}{l}\text { The verb precede means to come before something in time or when } \\
\text { in order position. Proceed means to move forward or to continue. "He } \\
\text { preceded me into the room;once I caught up with him I proceeded to } \\
\text { tell himoff." }\end{array}$ \\
\hline $\begin{array}{l}\text { principal / } \\
\text { principle }\end{array}$ & $\begin{array}{l}\text { Principal is a noun that means a person who holds a high position or } \\
\text { plays an important role: "The school principal has } 20 \text { years of teaching } \\
\text { experience." Principal is also an adjective that means chief or leading: } \\
\text { "The necessity of " }\end{array}$ \\
\hline $\begin{array}{l}\text { personal / } \\
\text { personnel }\end{array}$ & $\begin{array}{l}\text { Personal is private. (Rudi was unwilling to discuss his childhood; it was } \\
\text { too personal). } \\
\text { personnel is staff. (The personnel at the department store was made up } \\
\text { of young adults). }\end{array}$ \\
\hline $\begin{array}{l}\text { stationary / } \\
\text { stationery }\end{array}$ & $\begin{array}{l}\text { Stationary is an adjective that means not moving or not intend to be } \\
\text { moved or fixed position: "They maneuvered around the stationary } \\
\text { barrier in the road." } \\
\text { Stationery is a noun that refers to writing materials: "We printed the } \\
\text { letters on company stationery." }\end{array}$ \\
\hline $\begin{array}{l}\text { their / there } \\
\text { / they>re }\end{array}$ & $\begin{array}{l}\text { Their is the possessive form of they; } \\
\text { there refers to place; and they're is the contraction of they are. } \\
\text { "They're going there because their mother insisted they become } \\
\text { proficient in Serbo-Croatian." }\end{array}$ \\
\hline than / then & $\begin{array}{l}\text { Than/ then is conjunction. Used most commonly in comparisons. } \\
\text { (Maggie is older than I). } \\
\text { then is soon afterward. (We lived in Boston; then we moved to New } \\
\text { York) }\end{array}$ \\
\hline to / too & $\begin{array}{l}\text { To is direction of; toward. (She mades a turn to the right onto Mataram } \\
\text { street). } \\
\text { too is more than enough. (She served too much for dinner), another } \\
\text { meaning of too is also. }\end{array}$ \\
\hline $\begin{array}{l}\text { who }>\text { s } \\
\text { whose }\end{array}$ & $\begin{array}{l}\text { Who is is the contraction of who is or who has.It is not considered as } \\
\text { possessive even tough an an appostrophe followed by an } s \text {. } \\
\text { Whose is clearly the possessive form of who. "Who's going to figure out } \\
\text { whose job it is to clean the stables?" }\end{array}$ \\
\hline
\end{tabular}




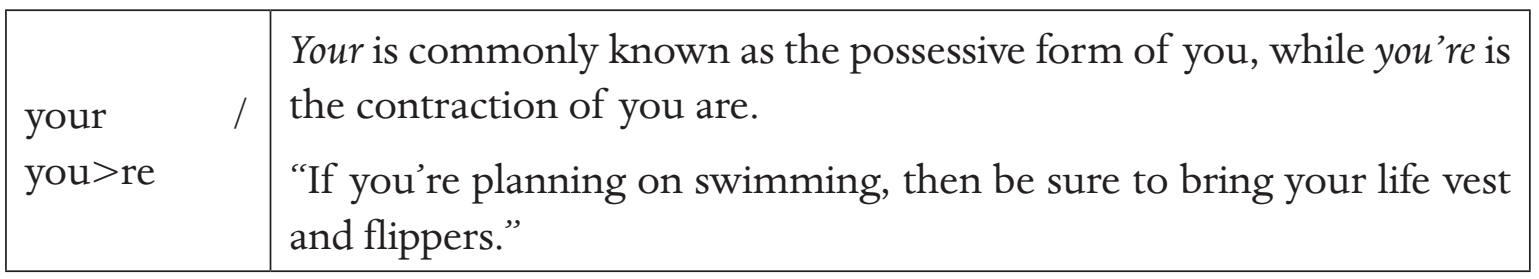

Beck et al. (2002) propose that on words' usefulness and frequency. To help in this endeavor, they categorized words into three steps: ${ }^{12}$

a. Step one consists of words such as clock, baby, and happy whose meanings students are likely to know.

b. Step two is made up of words such as fortunate, maintain, and merchant that are "likely to appear frequently in a wide variety of texts and in the written and oral language of mature language users" (2002, p.16), but whose meanings students are less likely to know.

c. Step three is made up of words such as irksome, pallet, and retinue that appear in text rarely. Although these rare words are often unknown to students, their appearance in texts is limited to one or two occurrences, and because they are often specific to particular content, students can use the context of texts to establish their meaning.

Graves (2000) identifies three types of word-learning tasks facing students: ${ }^{13}$

a. Words that are synonyms for words that students already know;

b. Words that students know at some level but that have multiple meanings, such as attention, channel, and practice; and

c. Words that represent concepts that may be new to students, such as liberty, probability, etc

\section{E. Conclusion}

Instruction in dictionary use that simply has students look up words and write definitions seldom produces indepth word knowledge (Scott \& Nagy, 1997). This is not to say that dictionaries are not important aids to word learning. It means that instruction must show students how to use the definitions they find in a dictionary. Effective dictionary instruction includes teacher modeling of how most effectively to look up an unknown word and thinking aloud about how to select which is the most appropriate definition for a particular context (Graves, et al., 2004).

$12{ }^{12}$ Beck, I. L., McKeown, M. G., \& Kucan, L. (2002). Bringing words to life: Robust vocabulary instruction. New York

$13{ }^{13}$ Graves, M. F. (2000). A vocabulary program to complement and bolster a middle-grade comprehension program. In B. M. Taylor, M. F. Graves, \& P. van den Broek (Eds.), Reading for meaning: Fostering comprehension in the middle grades (pp. 116-135). New York: Teachers College Press; Newark, DE: International Reading Association 
Dictionaries should be used in the foreign language, and what dictionaries, if at all, should be used has always been a lively one amongst language teachers who teach languages. Empirical research on dictionaries has largely focused on comparing the usefulness of dictionaries with that of guessing. Connecting important selection words to familiar synonyms before students read can be an efficient and minimally disruptive way to help them get the most from reading. In this way, students need to differentiate the words to function or content words since it will help them understand the text and context of the words. Furthermore, it is pivotal for teachers to provide further the instruction by writing on the board sentences that contain the target words and providing quick definitions that use synonyms students are likely to know. It is also recommended to be used in dictionary where words are not only lexically described, but also functionally stated.

\section{REFERENCES}

Baxter, James. (1980). The Dictionary and Vocabulary Behavior: A Single Word or a Handful? TESOL Quarterly, 14 (3), 325-336.

Beck, I. L., McKeown, M. G., \& Kucan, L. (2002). Bringing words to life: Robust vocabulary instruction. New York

Christianson, Kiel. (1997). Dictionary use by EFL writers: what really happens? Journal of Second Language Writing, 6 (1), 23-43.

Fukkink, R. G., \& de Glopper, K. (1998). Effects of instruction in deriving word meaning from context: A meta-analysis. Review of Educational Research, 68(4), 450-468.

Fogiel. M., (1994). REA’s Hand Book English Grammar, Style, and Writing. Research and Education Association 61 Ethel Road West Piscataway, New Jersey 08854. Printed in the USA.

Graves, M. F. (2000). A vocabulary program to complement and bolster a middle-grade comprehension program. In B. M. Taylor, M. F. Graves, \& P. van den Broek (Eds.), Reading for meaning: Fostering comprehension in the middle grades (pp. 116-135). New York: Teachers College Press; Newark, DE: International Reading Association.

Hornby, A. (1987). Oxford Advanced Learner's Dictionary of Current English. (Oxford: Oxford University Press, p. xiii.

Jullian, Paul. (2000). Creating word-meaning awareness. ELT Journal, 54 (1), 37-46

Miles, M. B., Huberman, A. M., \& Saldana, J. (2013). Qualitative Data Analysis: A Methods Sourcebook. Sage Publications, Incorporated. California. 
El-Tsaqafah: Jurnal Jurusan PBA, Vol. 18, No.2, Desember 2019

Miller, G., \& Gildea, P. (1987). How children learn words. Scientific American, 27, 9499.

Oelschlaeger, Mary L., Damico, Jack S. (2000). Partnership in conversation: A study of word search strategies. Journal of Communication Disorder, 33 (3), 205-225.

Scott, J. A., \& Nagy, W. E. (1997). Understanding the definitions of unfamiliar verbs. Reading Research Quarterly, 32, 184-200

Stahl, S.A.,\& Nagy, W.E.( 2000).Teaching Words Meaning. L. Erlbaum Associates, USA. 